Vincent Agnes Brigitta ${ }^{1}$, Chinnaiyan Thangavelu ${ }^{2}$

Susai Rajendran ${ }^{3 *}$, Abdulhameed Al-Hashem ${ }^{4}$

${ }^{1}$ SBM college of Engineering and Technology, Department of Chemistry, Thamaraipadi, Dindigul , Tamil Nadu, India, ${ }^{2}$ EVR Govt Arts College, Trichy, India, ${ }^{3}$ St. Antony's College of Arts and Science For Women, Research Center, Department of Chemistry, Thamaraipadi, Dindigul,Tamil Nadu, India, ${ }^{4}$ Kuwait Institute for Scientific Research (KISR), Petroleum Research Center,Kuwait
Scientific paper

ISSN 0351-9465, E-ISSN 2466-2585

UDC:620.197.2

doi: doi:10.5937/ZasMat1802182V

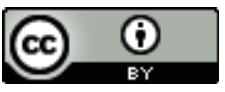

Zastita Materijala 59 (2)

182 - 188 (2018)

\title{
Corrosion resistance of SS18/8 alloy, SS316L alloy, Gold18carat and Gold 22 carat in artificial saliva in the absence and presence of erythromycin tablet $500 \mathrm{mg}$
}

\begin{abstract}
Corrosion resistance of SS18/8 alloy, SS316L alloy, Gold18carat and Gold 22 carat in artificial saliva in the absence and presence of Erythromycin tablet 500mg has been evaluated by electrochemical study such as polarization study. For SS316L alloy, Gold 18 carat and Gold 22 carat, Polarization study leads to the conclusion that corrosion resistance of SS316L alloy, Gold 18 carat and Gold 22 carat decreases in the order: AS + Erythromycin > AS. Hence, people clipped with an orthodontic wire made of SS316 alloy, Gold 18 carat and Gold 22 carat can take Erythromycin tablet orally without any hesitation. For SS18/8 alloy, polarization study leads to the conclusion that corrosion resistance of SS18/8 alloy decreases in the order: AS > AS + Erythromycin. So, people clipped with an orthodontic wire made of SS18/8, should avoid taking Erythromycin tablet orally.

Keyword: corrosion resistance, polarization study, orthodontic wire, SS18/8 alloy, SS316L alloy, Gold 18carat and Gold 22 carat, Erythromycin.
\end{abstract}

\section{INTRODUCTON}

Orthodontic treatment is vital for improving and maintaining good oral and dental health, as well as creating an attractive smile that contributes to the development of self -esteem. Saul M Castro et el [1]. Model wires should be designed to move teeth with continuous forces and should remain elastic [2]. Different wire alloys are available for orthodontic treatment. However, no wire is optimal for orthodontic applications during all the different stages of treatment [3]. The properties required for orthodontic wires depend on their application, Until the 1930s, the available orthodontic wires were made of gold. Austenitic SS was introduced as an orthodontic wire in 1929, and because of its superior strength, higher modulus of elasticity, good resistance to corrosion, and moderate costs, SS promptly gained acceptance and preference over gold [4].

\footnotetext{
*Corresponding author: Susai Rajendran

Email: susairajendran@gmail.com

Paper received: 03. 01. 2018.

Paper accepted: 19. 03. 2018.

Paper is available on the website:

www.idk.org.rs/journal
}

The alloy of SS most frequently used for orthodontic materials is the American Iron and Steel Institute type 304, containing $18-20 \%$ of chromium and $8-10 \%$ of nickel[ 3,5$]$. SS wires have good biocompatibility, good corrosion resistance, excellent formability, high yield strength, and high modulus of elasticity $[4,6]$.The corrosion is one of the most important problems which lead to the rejection of the implants or their components, the corrosion process can be accelerated by the defects appeared on the surface of the implants, during their manufacturing process. corrosion can be defined as the destruction of a certain substances, especially metal, in reaction with an environment [7]. The issue of corrosion has began to attract attention since the presence of a scientific research about the galvanic corrosion of dental compound about 40 years before [8]. Many metals and alloy have been used in dentistry. The corrosion behavior in artificial saliva has been investigated. Corrosion resistant of 18 Carat Gold in artificial saliva in presence of D-Glucose has been investigated by Saranya et al [9]. Corrosion resistance of SS316Lalloy in artificial saliva in presence of a sparkle Tooth paste has been 
investigated by Renita D' Souza et al [10]. Electrochemical corrosion behavior of Dental/ Implant alloy in artificial saliva has been investigated by Mohit Sharma et al [11].

Corrosion behavior of Metals in Artificial saliva in presence of D-Glucose, Spirulina powder and electrol have been investigated by Rajendran et al $[9,12,13]$. The corrosion resistance of orthodontic wire made of 18 Carat Gold, in artificial saliva in presence of a tablet Brufen 400mg has been investigated by MohamedKasim Shiet et al [14]. Corrosion resistance of two orthodontic wires made of thermoactive super elastic shape memory alloy and $22 \mathrm{k}$ gold in artificial saliva in the absence and presence of syzygium cumini extract has been evaluated by Madhumitha et al [15]. Corrosion resistance of super Elastic Nickel-Titanium alloy in artificial saliva in the absence and presence of tablets namely, Almox $250 \mathrm{mg}$ has been evaluated by Rajendran et al [16-23].Influence of Corrosion resistance of orthodontic wires in artificial saliva in the absence and presence of coffee has been investigated by Christy et al [24]. Corrosion inhibition By an aqueous extract of Aleovera, Henna leaves have been investigated by Sribharathi and Rajendran et al $[25,26]$. Corrosion Inhibition of Titanium in Artificial Saliva Containing Fluoride and Orthodontic Brackets have been investigated by Kinani et al $[27,28]$. Corrosion resistance of SS316L immersed in artificial saliva in presence of Ciprofloxacin tablet, Coca -Cola, Maaza, Sparkle Fresh have been evaluated by Mohamed Kasim,Devlin, Sangeetha, Renita et al. [29-31]. The present work was undertaken to study the Corrosion resistance of SS18/8 alloy, SS316L alloy, Gold 18carat and Gold 22 carat in artificial saliva in the absence and presence of Erythromycin tablet $500 \mathrm{mg}$. By a polarization study, corrosion parameters such as Corrosion potential $\mathrm{E}$ (corr), Linear polarization Resistance(LPR), Corrosion current $\left(\mathrm{I}_{\mathrm{Corr}}\right)$ and Tafel slopes (anodic= $b_{a}$ and cathodic $=b_{c}$ ) were calculated.

\section{MATERIALS AND METHODS}

Four metal/alloy specimen, namely, Stainless Steel18/8 (SS18/8), Gold18carat, Gold 22 carat, Stainless Steel 316L (SS316L) and were chosen for present study.The composition (SS18/8), Gold 18 carat, Gold 22 carat, and (SS316L) are given below the tables $1 \& 2$.

The metal specimens were immersed in Fusayama Meyer artificial saliva (AS) (Kinani,2007) containing Erythromycin tablet system, The composition of artificial saliva (AS) is given in Table 3.
Table 1. Composition of SS316L and SS18/8 alloys

Tabela 1. Sastav legura SS316L i SS18 / 8

\begin{tabular}{|l|c|c|}
\hline \multicolumn{2}{|c|}{ Composition of SS316L } & Composition of SS18/8 \\
\hline Carbon & $0.3 \%$ & $.08 \%$ \\
\hline Manganese & $2 \%$ & $2 \%$ \\
\hline Chromium & $16-8 \%$ & $18-20 \%$ \\
\hline Molybdenum & $2-3$ & - \\
\hline Nickel & $10-14 \%$ & $8-10.5 \%$ \\
\hline Iron & Bal & Bal \\
\hline Silicon & $1 \%$ & $1 \%$ \\
\hline Phosphorous & $.045 \%$ & $.045 \%$ \\
\hline Sulfur & $.03 \%$ & $.03 \%$ \\
\hline others & - & \\
\hline
\end{tabular}

Table 2. Composition of Gold22 carat and Gold18 carat

Tabela 2. Sastav legura zlato 22 karaka i zlato 18 karata

\begin{tabular}{|c|c|c|}
\hline Metals & Gold 22carat & Gold 18carat \\
\hline Gold & $91.6 \%$ & $75 \%$ \\
\hline Silver & $5 \%$ & $10-205$ \\
\hline Copper & $2 \%$ & $5-15 \%$ \\
\hline Zinc & $1.33 \%$ & ---- \\
\hline
\end{tabular}

Table 3. Composition of Artificial Saliva

Tabela 3. Sastav veštačke pljuvačke

\begin{tabular}{|c|c|c|}
\hline S.No & Name of the chemicals & Weight/lit \\
\hline 1. & $\mathrm{NaCl}$ & $0.4 \mathrm{~g}$ \\
\hline 2. & Urea & $1 \mathrm{~g}$ \\
\hline 3. & $\mathrm{KCl}$ & $0.4 \mathrm{~g}$ \\
\hline 4. & $\mathrm{CaCl}_{2} \mathrm{H}_{2} \mathrm{O}$ & $0.906 \mathrm{~g}$ \\
\hline 5. & $\mathrm{NaH}_{2} \mathrm{PO}_{4} .2 \mathrm{H}_{2} \mathrm{O}$ & $0.690 \mathrm{~g}$ \\
\hline 6. & $\mathrm{Na}_{2} \mathrm{~S} .9 \mathrm{H}_{2} \mathrm{O}$ & $0.005 \mathrm{~g}$ \\
\hline
\end{tabular}

\subsection{Polarization Study}

Polarization Studies were carried out in a CHIElectrochemical work station with impedance. A three electrode cell assemblies were used. The working electrode was one of the four metals. A saturated Calomel electrode [SCE] was the reference electrode and platinum electrode was the counter electrode. From the polarization study corrosion parameters such as Corrosion Potential $\left(\mathrm{E}_{\text {Corr }}\right)$, Linear polarization Resistance(LPR), Corrosion Current $\left(\mathrm{I}_{\mathrm{Corr}}\right)$ and Tafel slopes (anodic= ba and cathodic $=$ bc) were calculated. 


\section{RESULT AND DISCUSSION}

\subsection{Analysis of Potentiodynamic polarization} curves

Corrosion resistance of SS18/8 alloy, Gold18carat, Gold 22 carat and SS316L alloy

Table 4. Corrosion parameters of metals immersed in Artificial Saliva(AS) in the absence and presence of Erythromycin tablets, Obtained by polarization study

Tabela 4. Parametri korozije metala uronjenih u veštačku pljuvačku (AS) u odsustvu i prisustvu tableta Erithromicin, dobiveni polarizacijom

\begin{tabular}{|l|l|c|c|c|c|c|}
\hline \multicolumn{1}{|c|}{ Metal } & System & Ecorr $\mathrm{mV}$ vs SCE & $\mathrm{b}_{\mathrm{c}} \mathrm{mV} /$ decade & $\mathrm{b}_{\mathrm{a}} \mathrm{mV} /$ decade & LPR Ohmcm & $\mathrm{I}_{\text {corr }} \mathrm{A} / \mathrm{cm}^{2}$ \\
\hline \multirow{2}{*}{ SS18/8 } & AS & -501 & 0.182 & 0.245 & 1604576.8 & $2.834 \times 10^{-}$ \\
\cline { 2 - 7 } & AS+Erythromycin & -481 & 0.209 & 0.204 & 1259706.8 & $3.574 \times 10^{-}$ \\
\hline \multirow{2}{*}{$\begin{array}{l}\text { Gold } \\
18 \text { carat }\end{array}$} & AS & -113 & 0.160 & 0.215 & 2118899 & $1.889 \times 10^{-}$ \\
\cline { 2 - 7 } & AS+Erythromycin & -102 & 0.139 & 0.185 & 3916073.3 & $8.838 \times 10^{-}$ \\
\hline \multirow{2}{*}{$\begin{array}{l}\text { Gold } \\
\text { 22 carat }\end{array}$} & AS & -057 & 0.103 & 0.287 & 5935387 & $5.594 \times 10^{-}$ \\
\cline { 2 - 7 } & AS+Erythromycin & -106 & 0.134 & 0.37 & 5964082 & $7.217 \times 10^{-}$ \\
\hline \multirow{2}{*}{ SS316L } & AS & -544 & 0.174 & 0.255 & 777108.8 & $5.809 \times 10^{-}$ \\
\cline { 2 - 7 } & AS+Erythromycin & -434 & 0.175 & 0.232 & 1284415.5 & $3.385 \times 10^{-}$ \\
\hline
\end{tabular}

\section{SS18/8 alloy}

Polarisation curves of SS18/8 alloy immersed in various test solutions are shown in figure1.The corrosion parameters namely Corrosion Potential $\left(E_{\text {corr }}\right)$, Tafel slopes $\left(b_{c}=\right.$ cathodic; $\mathrm{b}_{\mathrm{a}}=$ anodi) Linear Polarization Resistance (LPR) and Corrosion current $\left(\mathrm{I}_{\text {corr }}\right)$ are shown in table 4.

When SS18/8 immersed in Artificial Saliva (AS), Linear Polarization Resistance (LPR) value is $1604576.80 \mathrm{hm} \mathrm{cm}^{2}$. The Corrosion current $\left(\mathrm{I}_{\text {corr }}\right)$ is $2.834 \times 10^{-8} \mathrm{~A} / \mathrm{cm}^{2}$. The Corrosion Potential $\left(E_{\text {corr }}\right)$ is $-501 \mathrm{mV}$ vs SCE.

When SS18/8 is immersed in AS containing Erythromycin tablet system, Linear Polarization Resistance (LPR) value decreases from 1604576.8 to1259706.8 ohm $\mathrm{cm}^{2}$. The Corrosion current $\left(\mathrm{I}_{\text {corr }}\right)$ increases from $2.834 \times 10^{-8}$ to $3.574 \times 10^{-8} \mathrm{Al} \mathrm{cm} \mathrm{cm}^{2}$. immersed in various test solutions are given in Table 4. The potentiodynamic polarization curves are shown in Figure1-4. When corrosion resistance increases Linear Polarization Resistance (LPR) increases; Corrosion current $\left(\mathrm{I}_{\text {corr }}\right)$ decreases.
This indicates that SS18/8 alloy is less corrosion resistance in AS containing Erythromycin tablet system. Further the Corrosion Potential $\left(E_{\text {corr }}\right)$ value shifts from $-501 \mathrm{mV}$ to $-481 \mathrm{mV}$ vs SCE. The corrosion resistance of SS18/8 alloy is less in AS in presence of Erythromycin tablet than AS (absence of Erythromycin tablet) alone. Thus the polarization study leads to the conclusion that when SS18/8 alloy is immersed in various test solutions, the decreasing order of corrosion resistance is as follows:

\section{AS $>$ AS + Erythromycin}

This study reveals that people should avoid taking Erythromycin tablet orally while clipping of an orthodontic wires made of SS18/8 alloy, for its corrosion resistant is very less in this medium of AS + Erythromycin system.

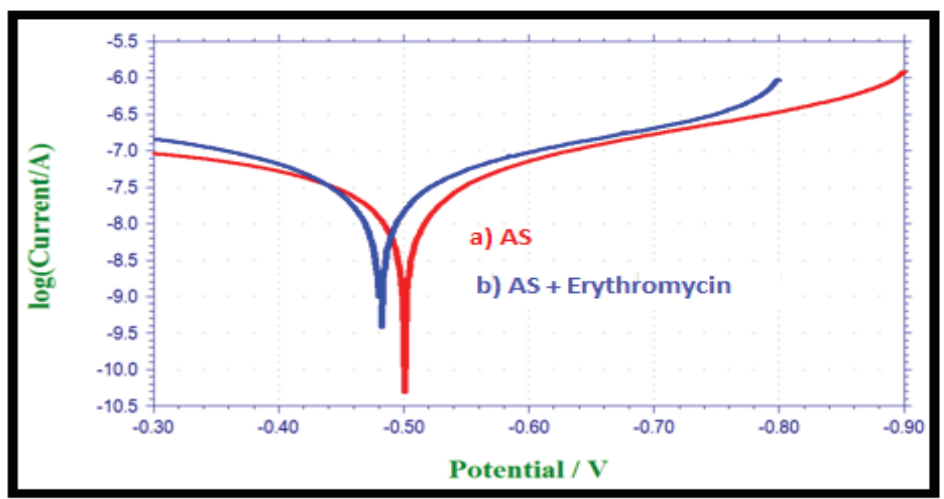

Figure 1. Polarization curves of SS18/8alloy immersed in various test solutions, a) AS, b) AS + Erythromycin

Slika 1. Polarizacijske krive legure SS 18 / 8 uronjene u različite testne rastvore, a) AS b) AS + Eritromicin 


\section{Gold 18 carat}

When Gold 18 carat immersed in Artificial Saliva (AS), polarisation curves are shown in Figure 2. Linear Polarization Resistance (LPR) value is2118899 ohm $\mathrm{cm}^{2}$. The Corrosion current $\left(I_{\text {corr }}\right)$ value is $1.889 \times 10^{-8} \mathrm{~A} / \mathrm{cm}^{2}$. The Corrosion Potential $\left(E_{\text {corr }}\right)$ is $-113 m V$ vs SCE.

When Gold 18 carat immersed in AS containing Erythromycin tablet system polarisation curves are shown in Figure 2. Linear Polarization Resistance (LPR) value increases from 2118899 to $3916073.30 \mathrm{hm} \mathrm{cm}^{2}$. The Corrosion current $\left(\mathrm{I}_{\text {corr }}\right)$ decreases from $3.574 \times 10^{-8}$ to $8.838 \times 10^{-9} \mathrm{~A} / \mathrm{cm}^{2}$. This values suggest that Gold 18 carat in AS presence of Erythromycin tablet is more corrosion resistant than AS alone. Further the Corrosion Potential $\left(E_{\text {corr }}\right)$ value shifts from $-113 m \mathrm{~m}$ to -
$102 \mathrm{mV}$ vs SCE. This value reveals that a protective film formed on the metal surface, which controlled the rate of corrosion of the metal alloy in AS in the presence of Erythromycin tablet. The nature of the protective film has to be analyzed in a future study. Thus the polarization study leads to the conclusion that when Gold18 carat is immersed in various test solutions, the decreasing order of corrosion resistance of Gold18 carat is as follows:

\section{AS + Erythromycin $>A S$}

This study reveals that people clipped with an orthodontic wires made of Gold18 carat can take Erythromycin tablet orally without any hesitation, because in this medium (AS + Erythromycin system) the corrosion resistance of Gold18 carat is higher.

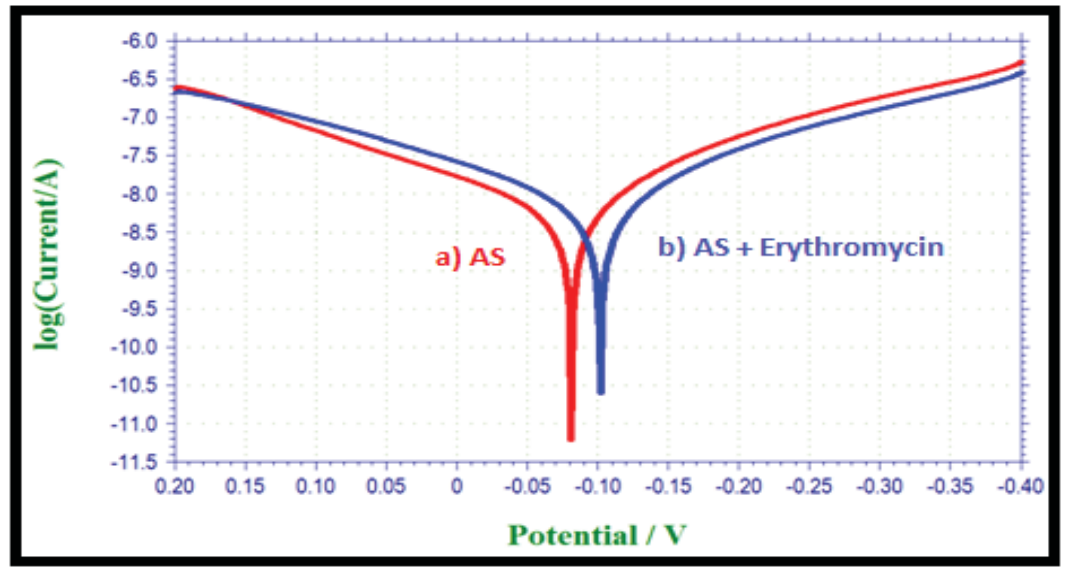

Figure 2. Polarization curves of Gold18 carat immersed in various test solutions a) AS, b) AS + Erythromycin

Slika 2. Polarizacijske krive zlata 18 karata uronjenog u različite testne rastvore a) $A S$, b) $A S+$ Eritromicin

\section{Gold 22 carat}

When Gold 22 carat immersed in Artificial Saliva (AS) the polarisation curves are shown in Figure 3. Linear Polarization Resistance (LPR) value is $5935387 \mathrm{ohm} \mathrm{cm}^{2}$. The Corrosion current $\left(\mathrm{I}_{\text {corr }}\right) \quad 5.594 \times 10^{-9} \mathrm{~A} / \mathrm{cm}^{2}$. The Corrosion Potential $\left(\mathrm{E}_{\text {corr }}\right)$ is $-057 \mathrm{mV}$ vs SCE.

When Gold 22 carat immersed in AS in the presence of Erythromycin tablet the polarisation curves are shown in Figure 3.The Linear Polarization Resistance (LPR) values increases a little more from 5935387 to 5964082 ohmcm2. The Corrosion current ( $\left.\mathrm{I}_{\text {corr }}\right)$ decreases from $5.594 \times 10^{-9}$ to $7.217 \times 10^{-9} \mathrm{~A} / \mathrm{cm}^{2}$. These values suggest that Gold 22 carat is more corrosion resistant in AS in presence of Erythromycin tablet than in the absence of Erythromycin tablet in AS.
Further the Corrosion Potential $\left(E_{\text {corr }}\right.$ ) value shifts from $-057 \mathrm{mV}$ vs SCE to $-106 \mathrm{mV}$ vs SCE. A protective film forms on the metal surface. Due to the formation of the protective film, corrosion resistance of Gold 22 carat increases in the presence of Erythromycin tablet in AS. Thus the polarization study leads to the conclusion that when Gold 22 carat is immersed in various test solutions, the decreasing order of corrosion resistance of Gold18 carat is as follows:

$$
A S+\text { Erythromycin }>A S
$$

This study reveals that the people clipped with an orthodontic wires made of Gold 22 carat can also take Erythromycin tablet orally without any fear, because in this medium of AS + Erythromycin the corrosion resistance of Gold 22 carat is higher. 


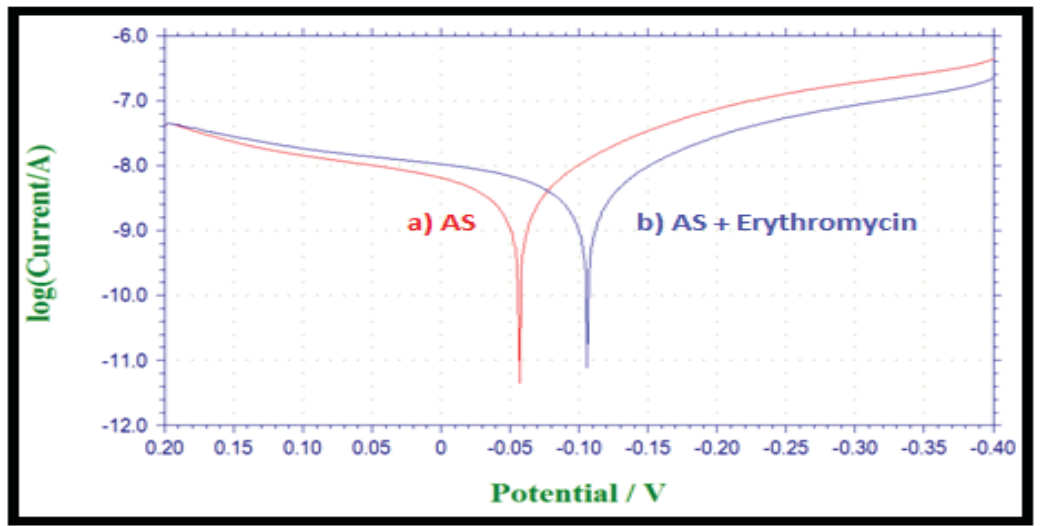

Figure 3. Polarization curves of Gold 22 carat immersed in various test solutions, a) $A S$, b) $A S+$ Erythromycin

Slika 3. Polarizacijske krive zlata 22 karata uronjenog u različite testne rastvore, a) $A S, b) A S+$ Eritromicin

SS316L alloy

When SS316L immersed in Artificial Saliva (AS) the polarisation curves are shown in Figure 4. Linear Polarization Resistance (LPR) value is $777108.80 \mathrm{hm} \mathrm{cm} \mathrm{cm}^{2}$. The Corrosion current $\left(I_{\text {corr }}\right)$ is $5.809 \times 10^{-8} \mathrm{~A} / \mathrm{cm}^{2}$. The Corrosion Potential ( $\left.E_{\text {corr }}\right)$ is $-544 \mathrm{mV}$ vs SCE.

When SS316L immersed in AS containing Erythromycin tablet as shown in Figure 4, it is interesting to note that the Linear Polarization Resistance (LPR) value increases to a greater extent from 777108.8 to1284415.5ohm $\mathrm{cm}^{2}$ and also the Corrosion current $\left(\mathrm{I}_{\text {corr }}\right)$ decreases from $5.809 \times 10^{-8}$ to $3.385 \times 10^{-8} \mathrm{~A} / \mathrm{cm}^{2}$. This indicates that SS316L is more corrosion resistant in presence of Erythromycin tablet in AS than AS alone. Further the Corrosion Potential $\left(E_{\text {corr }}\right)$ value shifts from $544 \mathrm{mV}$ vs SCE to $-434 \mathrm{mV}$ vs SCE. This is due to the formation of an effective protective film formed on the metal surface. This protective film controls the rate of corrosion of the SS316L alloy. Hence, the corrosion resistance of SS316L increases in the presence of Erythromycin tablet in AS than AS alone. Thus the polarization study leads to the conclusion that when SS316L alloy is immersed in various test solutions, the decreasing order of corrosion resistance of SS316L alloy is as follows:

$$
\text { AS + Erythromycin > AS }
$$

This study suggests that the people clipped with an orthodontic wires made of SS316L alloy, there is no problem in taking Erythromycin tablet orally, because, in this medium (AS + Erythromycin) the corrosion resistance of SS316L alloy is higher.

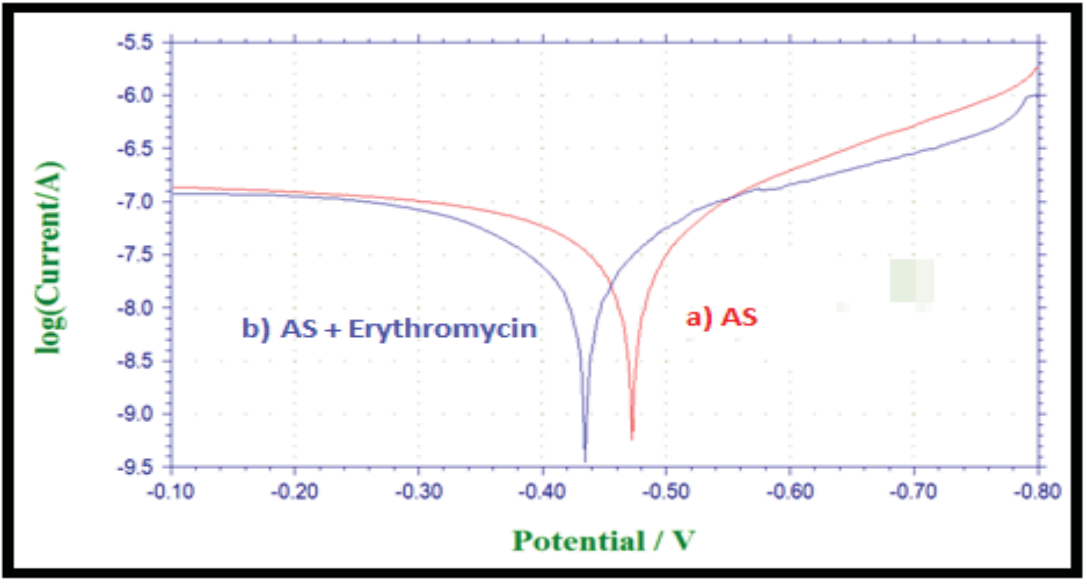

Figure 4. Polarization curves of SS316L alloy immersed in various test solutions a) AS, b) AS + Erythromycin

Slika 4. Polarizacijske krive legure SS316L uronjene u različite testne rastvore a) $A S$, b) $A S+$ Eritromicin 


\section{CONCLUSION}

1. For SS18/8 alloy, the polarization study leads to the conclusion that when SS18/8 alloy is immersed in various test solutions, the decreasing order of corrosion resistance is as follows:

\section{$A S>A S+$ Erythromycin}

2. This study reveals that people should avoid taking Erythromycin tablet orally while clipping of an orthodontic wires made of SS18/8 alloy, for its corrosion resistant is very less in this medium of AS + Erythromycin system.

3. For Gold 18 carat, the polarization study leads to the conclusion that when Gold18 carat is immersed in various test solutions, the decreasing order of corrosion resistance of Gold18 carat is as follows:

\section{$A S+$ Erythromycin $>A S$}

4. This study reveals that people clipped with an orthodontic wires made of Gold18 carat can take Erythromycin tablet orally without any hesitation, because in this medium (AS + Erythromycin system) the corrosion resistance of Gold18 carat increases.

5. For Gold 22 carat, the polarization study leads to the conclusion that when Gold 22 carat is immersed in various test solutions, the decreasing order of corrosion resistance of Gold18 carat is as follows:

$$
\text { AS + Erythromycin }>A S
$$

6. This study reveals that the people clipped with an orthodontic wires made of Gold 22 carat can also take Erythromycin tablet orally without any fear, because in this medium of AS + Erythromycin the corrosion resistance of Gold 22 carat increases.

7. For SS18/8 alloy, the polarization study leads to the conclusion that when SS316L alloy is immersed in various test solutions, the decreasing order of corrosion resistance of SS316L alloy is as follows:

$A S+$ Erythromycin $>A S$

8. This study suggests that the people clipped with an orthodontic wires made of SS316L alloy , There is no problem to take Erythromycin tablet orally, because in this medium (AS + Erythromycin) the corrosion resistance of SS316L alloy increases.

Further, the study reveals the following facts

1. In AS system Gold 18 carat is more corrosion resistant than SS18/8 alloy.

2. In AS system, Gold 22 carat is more corrosion resistant than Gold 18 carat.

3. In AS system, Gold 22carat is more corrosion resistant than SS316L alloy.

4. In AS system SS18/8 is more corrosion resistant than SS316L.

5. In AS Containing Erythromycin tablet system ,Gold 18 carat is more corrosion resistant than SS18/8 alloy.
6. In AS Containing Erythromycin tablet system, Gold 22 carat is more corrosion resistant than Gold 18 carat.

7. In AS Containing Erythromycin tablet system Gold22carat is more corrosion resistant than SS316L alloy.

8. In AS Containing Erythromycin tablet system SS316L alloy is more corrosion resistant than SS18/8.

\section{Aknowledgement}

The authors are thankful to their respective managements, for their constant help and encouragement.

\section{REFERENCES}

[1] S.M.Castro, J.Maria Ponces, D.Jorge Lopes, M. Va sconcelos, C. F. Maria Pollmann (2015) Orthodontic Wires and its Corrosion-The Specific case of Stainless Steel and beta- titanium, Review Article, Journal of Dentaql Science, 10, 1-7.

[2] C.C.A.Quinta o, I.H.Brunharo (2009) Orthodontic wires: knowledge ensures clinical optimization, Dental Press J Orthod, 14, 144-157.

[3] R.P.Kusy (1997) A review of contemporary archwires: their properties and characteristics, Angle Orthod, 67, 197-207.

[4] A.Verstrynge, J.Van Humbeeck, G.Willems (2006) In-vitro evaluation of the material characteristics of stainless steel and betatitanium orthodontic wires, Am J Orthod Dentofacial Orthop, 130, 460470.

[5] S.Kapila, R.Sachdeva (1989) Mechanical properties and clinical applications of orthodontic wires, Am J Orthod Dentofacial Orthop, 96, 100-109.

[6] K.TOh, S.U.Choo, K.M.Kim, K.N.Kim (2005) A stainless steel bracket for orthodontic application, Eur. J. Orthod, 27, 237-244.

[7] C.J.Burstone, A.J.Goldberg (1980) Beta titanium: a new orthodontic alloy, Am J Orthod, 77(2), 121-132.

[8] D.Meghea, M.Miculescu,C.C.Cotrut, M.Bane, A,Ghe rghilescu, D.M.Vranceanu (2015) Corrosion behaviour of $\mathrm{Ti}$ and $\mathrm{Ti}$ based alloys used as implants supported mandibular over dentures, ISSN, 1662- 9795, 638, 31-37.

[9] R.Saranya, Susai Rajendran,R.Krishnaveni and J.Jeyasundary (2013) Corrosion resistance of 18 Cara Gold in artificial saliva in presence of DGlucoseEur, Chem.Bull, 2(6), 389-392.

[10] D Renita Souza, A.Chattree and S. Rajendran (2017) Corrosion resistance of SS316L alloy in artificial saliva in presence of a Sparkle Toothpaste, Portugaliae Electrochemical Acta, 35(6), 339-350.

[11] Mohit Sharma, A.V.Ramesh Kumar, Nirbhay Singh, Nidhi Adya, and Babin Saluja (2008) Electrochemical Corrosion Behaviour of Dental/ Implant Alloys in Artificial Saliva, JMEPEG, 17(5), 695-701.

[12] S.Rajendran, J.Paulraj, P.Rengan, J.Jeyasundari, M.Manivannan (2009) Corrosion Behavior of Metal in Artificial Saliva in Presence of Spirulina Powder, Journal of Dentistry and Oral Hygiene, 1, 1-8.

[13] S.Rajendran, P. Chitradevi, S. Johnmary, A. Krishnaveni, S. Kanchana, Lydia Christy, R. Nagalakshmi, B.Narayanasamy (2010) Corrosion behaviour of SS316 L in artificial saliva in presence of electral, Zastita Materijala, 51(3), 149-158. 
[14] H.Mohamed Kasim Sheit, M.Seeni Mubarak, S.S. Syed Abuthahir, S.Rajendran (2017) Corrosion behaviour of 18 carat gold with artificial saliva in presence of brufen $400 \mathrm{mg}$ tablet, Int. J.Nano Corros. Sci and Engg, 4(1), 58-66.

[15] S.Madhumitha, V.Priyadharshini, A.Sheela, C.Aadhithya, M.Sangeetha, S.Rajendran (2016) Can people implanted with orthodontic wires made of thermoactive superelastic shape memory alloy and $22 \mathrm{k}$ gold take syzygium cumini fruit juice orally, Int.J.Nano Corros.Sci and Engg., 3(4), 80 - 87.

[16] C.A.Loto, A.I.Mohammed (2003) Inhibition evaluation of mango juice extracts on the corrosion of mild steel in $\mathrm{HCl}$, Corrosion Prevention and Control, 50(3), 107-118.

[17] C.A.Loto, A.I.Mohammed (2000) The effect of cashew juice extract on corrosion inhibition of mild steel in $\mathrm{HCl}$, Corrosion Prevention and Control, 47(2), 50-56.

[18] J.C.Da Rocha, J.A.da Cunha Ponciano Gomes, E.D.Elia (2010) Corrosion inhibition of carbon steel in hydrochloric acid solution by fruit peel aqueous extracts, Corrosion Science, 52(7), 2341-2348.

[19] P.C.Okafor, E.E.Ebenso (2007) Inhibitive action of Carica papaya extracts on the corrosion of mild steel in acidic media and their adsorption characteristics, Pigment and Resin Technology, 36(3), 134-140.

[20] S.L.Priya, A.Chitra, S.Rajenderan, K.Anuradha (2005) Corrosion behavior of aluminium in rain water containing garlic extract, Surface Engineering, 21(3), 229-231.

[21] A.Bouyanzer, B.Hammouti (2004) Naturally occurring ginger as corrosion inhibitor for steel in molar hydrochloric acid at $353 \mathrm{~K}$, Bulletin of Electrochemistry, 20(2), 63-65.

[22] A.Singh, M.A.Quraishi (2015) The extract of Jamun (Syzygiumcumini) seed as green corrosion inhibitor for acid media, Research on Chemical Intermediates, 41(3), 2901-2914

\section{IZVOD}

\section{KOROZIJSKA OTPORNOST LEGURE SS 18/8, LEGURE SS316L, ZLATA 18 KARATA I ZLATA 22 KARATA U VEŠTAČKOJ PLJUVAČKI U ODSUSTVU I PRISUSTVU TABLETA ERITROMICINA 500mg}

Otpornost na koroziju legure SS 18/8, legure SS316L, zlata 18 karata i zlata 22 karata u veštačkoj pljuvački u odsustvu i prisustvu tablete Erithromicin $500 \mathrm{mg}$ je procenjena elektrohemijskim ispitivanjem, kao što je ispitivanje polarizacije. Za leguru SS316L, zlato 18 karata i zlato 22 karata, studija polarizacije dovodi do zaključka da se otpornost na koroziju legure SS316L, Gold 18 karata i Gold 22 karata smanjuje u redosledu: AS + Erithromicin> AS. Stoga, ljudi koji u sebi imaju ortodontsku žicu izrađenu od legure SS316, zlato 18 karata $i$ zlato 22 karata, mogu uzimati Eritromicin tablete oralno bez ikakvih oklevanja. Za leguru SS 18/8, studija polarizacije dovodi do zaključka da se otpornost na koroziju legure SS 18/8 smanjuje u redosledu: AS> AS + Erithromicin. Dakle, ljudi koji u imaju u sebi ortodontsku žicu izrađeniu od legure SS 18/8, treba izbegavati uzimanje Eritromicin tablete oralno.

Ključne reči: otpornost na koroziju, ispitivanje polarizacije, ortodontska žica, legure SS18/8, legure SS316L, zlato 18 karata, zlato 22 karata, eritromicin.

Naučni rad

Rad primljen: 03. 01. 2018.

Rad prihvaćen: 19. 03. 2018.

Rad je dostupan na sajtu: www.idk.org.rs/casopis

(c) 2018 Authors. Published by Engineering Society for Corrosion. This article is an open access article distributed under the terms and conditions of the Creative Commons Attribution 4.0 International license (https://creativecommons.org/licenses/by/4.0/) 